\title{
Effects of Hydro and Hormonal Seed Priming on Seed Germination of Milk Thistle under Saline Stress Condition
}

\author{
Yousef NASIRI ${ }^{1 *}$, Parisa FEYZI ${ }^{2}$, Abdollah JAVANMARD ${ }^{3}$ \\ ${ }^{1}$ University of Maragheh, Faculty of Agriculture, Department of Agronomy and Plant Breeding, Maragheh, Iran; \\ ysfnasiri@maragheh.ac.ir\&ysfnasiri@yahoo.com (*correspondingauthor) \\ ${ }^{2}$ University of Maragheh, Faculty of Sciences, Department of biology, Maragheh, Iran; pfeyzi@yahoo.com. \\ ${ }^{3}$ University of Maragheh, Faculty of Agriculture, Department of Agronomy and Plant Breeding, Maragheh, Iran; javansohaib@gmail.com
}

\begin{abstract}
Salinity is an abiotic stress which has harmful effects on germination of many plants. Therefore, high germination rate and vigorous early growth under salty soils is preferred. Seed priming is a way to increase salt tolerance of plants. An experiment was conducted to investigate the effect of seed priming on germination of milk thistle under salinity condition. The treatments were 4 levels of seed priming (no priming, distilled water as hydro priming and 0.5 and $1.0 \mathrm{mM}$ salicylic acid) and 5 levels of salinity (0, 40 and $80 \mathrm{mM} \mathrm{NaCl}$ and 40 and $80 \mathrm{mM} \mathrm{CaCl}_{2}$ ). The experiment arranged as a factorial in a completely randomized design (CRD) with three replications. Results showed that salinity decreased germination percentage and germination rate to about 16 and $32 \%$ in $80 \mathrm{mM} \mathrm{CaCl}_{2}$ level compared to control, respectively. The highest mean germination time (5.7 day) were belonged to $80 \mathrm{mM}$ $\mathrm{CaCl}_{2}$. Radicle and plumule length significantly decreased by $80 \mathrm{mM} \mathrm{NaCl}$ and 40 and $80 \mathrm{mM} \mathrm{CaCl}_{2}$. The lowest seedling weight and seed stamina observed in $80 \mathrm{mM} \mathrm{CaCl}_{2} .0 .5 \mathrm{mM}$ salicylic acid improved all traits except mean germination time as compared to control. Salicylic acid $(0.5 \mathrm{mM})$ improved radicle length under 0,40 and $80 \mathrm{mM} \mathrm{NaCl}$ salinity levels as well as increased plumule length at the 0 and $40 \mathrm{mM} \mathrm{NaCl}$ salinity conditions.
\end{abstract}

Keywords: germination, salicylic acid, salt stress, seed priming, Silybum marianum

\section{Introduction}

Milk thistle (Silybum marianum L.) is an annual or biannual plant of the Asteraceae family. This plant is known commercially as a medicinal plant in Europe, Egypt, China, Argentina and Iran but it has been reported as a deleterious weed in some countries (Khan et al., 2009; Shokrpour et al., 2007; Zehtab-Salmasi and Moghbeli, 2008). Milk thistle is used for treatment of some disorders such as liver and gastrointestinal disease and poisoning caused by several funguses (Dvorak et al., 2003; Ram, et al., 2000). Seeds of this plant are commonly used as a medicinal drug. Its therapeutic properties are due to the presence of silymarin. The seeds contain the highest amount of silymarin, but the whole organs of plant are used medicinally (Geneva et al., 2008; Veres and Tyr, 2012).

Soil salinity as one of the main factors limit agricultural production and have been affected almost 80 million hectares of arable lands in arid, semi-arid and seaside regions of the world (Abo-Kassem, 2007; Allakhverdiev et al., 2000; FAO, 2008; Liopa-Tsakalidi et al., 2011; Mohammadi, 2009; Yamaguchi and Blumvald, 2005). Salinity is defined as the presence of high levels of minerals (Cations such as $\mathrm{K}$, $\mathrm{Mg}, \mathrm{Ca}, \mathrm{Na}$ and anions such as $\mathrm{NO}, \mathrm{HCO}, \mathrm{SO}, \mathrm{Cl}$ ) in water and soil (Tanji, 1995). Seed germination and seedling growth are the most sensitive stages in the biological life cycle of the plants. These stages affected by environmental factors such as temperature, soil moisture and salinity (Abo-Kassem, 2007; Cheng and Bradford, 1999; Khan and Gulzar, 2003). Salt and osmotic stresses are serious factors limit seed germination and are responsible for delayed seed germination and seedling establishment (Mohammadi, 2009; Thiam et al., 2013). Salinity affects the germination rate and percentage, seedling growth and many germination parameters such as germination index, radicle and plumule length, fresh and dry weight etc. in different methods depending on the plant species (El-Keblawy and Al-Rawai, 2005; Demir and Mavi, 2008; Sayar et al., 2010; Thiam et al., 2013; Zahedi et al., 2011).

Seed priming as a pre-sowing technique can improve radicle emergence, germination rate, germination vigor, seedling establishment and yield by making changes in metabolic activities in the seeds of many crops (Bodsworth and Bewley, 1981; Dell Aquila and Tritto, 1991; Taylor and Harman, 1990). Different priming techniques such as 
hydropriming, osmopriming, halopriming and hormone priming are used to improve seed germination and seedling growth (Basra et al., 2002; Carvalho et al., 2011; Eisvand et al., 2011). Priming is a procedure that partially hydrates seed in a specific environment, followed by drying of seed, so that germination processes begin, but radicle emergence does not occur (Dell Aquila and Tritto, 1991; Giri and Schillinger, 2003).

Salicylic acid (SA) as an endogenous regulator of plant metabolism plays an important role in plant defense mechanisms against adverse environmental conditions. It is well documented that SA is involved in biotic and abiotic stress (Dat et al., 1998; Shakirova et al., 2003; Yalpani et al., 1994). SA may affect directly on specific enzymes function or may activate the genes responsible for protective mechanisms (Horvath et al., 2007). It is found that SA can enhance activity of antioxidant enzymes like catalase and peroxidase to cope with oxidative stress. Application of exogenous SA enhanced the drought and salt stress resistance of plants (Senaratna et al., 2000; Tari et al., 2002). Application of SA for seed priming of different crops to improve seed germination and reduce the effects of soil salinity has been reported in many studies (Entesari $e t$ al., 2012; Erdal et al., 2011; Khan et al., 2009; Misra and Misra, 2012).

Farahmandfar et al. (2013) reported that seed priming of fenugreek by salicylic acid improved the dry weight and length of plumule and radicle under salt stress. Farhbakhsh (2012) also reported that application of 0.25 and $0.5 \mathrm{mM}$ of salicylic acid for seed priming of fennel were effective on germination percentage and rate, seed stamina index, hypocotyl and radicle length, fresh and dry weight under different water potentials $(0,-2,-4$ and -6 bar). Increase the tolerance to salinity by seed priming with salicylic acid reported in faba bean genotypes (Azooz, 2009). Dry weight of seedlings of wheat raised from seeds primed with SA improved as compared to the seeds non-treatment of SA under non salinity and salinity conditions (Bahrani and Pourreza, 2012).

Since, salinity is one of the most important factors that limit seed germination and production of many crops, and seed priming is a technique for decrease effects of salinity, so, this research was carried out to evaluate the effect of seed priming with water and different concentrations salysilic acide on germination and seedling growth behaviors of milk thistle under salinity stress conditions.

\section{Materials and methods}

This study was conducted in a seed laboratory of Agronomy and Breeding Plants Department, University of Maragheh, Maragheh, Iran in 2013. The experiment with seeds of milk thistle was conducted as a factorial in a completely randomized design (CRD) with three replications. Treatments included 4 levels of seed priming (no priming as control), hydro priming (HP) and $0.5 \& 1.0$ $\mathrm{mM}$ salicylic acid (SA)) and 5 levels of salinity $(0,40$ and 80 $\mathrm{mM}$ sodium chloride $(\mathrm{NaCl})$ and 40 and $80 \mathrm{mM}$ calcium chloride $\left.\left(\mathrm{CaCl}_{2}\right)\right)$. Before seed planting, salicylic acid solutions in three concentrations $(0,0.5$ and $1.0 \mathrm{mM})$ were prepared. Similar seed size and weight were surface sterilized in $5 \%(\mathrm{v} / \mathrm{v})$ sodium hypochlorite for $5 \mathrm{~min}$ to eliminate microorganisms and thoroughly washed with sterile tap water several times (Khan, et al., 2009; Korkmaz, 2005). Then 50 grams of sterilized seeds were immersed in $250 \mathrm{~mL}$ of the SA solutions and distilled water (with the ratio 1:5 $\mathrm{gmL}^{-1}$ ) for 6 hours at room temperature. Thereafter, the seeds from each solution were washed in a sieve and rinsed under running tap water for one minute and left to surface dried on filter paper under room conditions until their moisture content reached to the original weight (Carvalho et al., 2011).

Before placing the seeds in the seed bed, the petri dishes and filter papers were sterilized into Autoclave at $121^{\circ} \mathrm{C}$ for $20 \mathrm{~min}$. The 25 seeds from each SA solution and without priming collection were transferred on Whatman filter paper No. 1 in sterilized Petri dishes $(9 \mathrm{~cm}$ diameter) separately and $5 \mathrm{ml}$ of each saline solution were added to related treatment. All petri dishes containing seeds were sealed to prevent the loss of moisture and avoid contamination. Finally, the petri dishes containing seeds were transferred to a growth chamber at a day/night cycle of $16 \mathrm{~h} / 8 \mathrm{~h}$ at $25{ }^{\circ} \mathrm{C}$. Seeds were watered with desired concentration of salinity treatments that are already prepared as needed. A seed germination scored when root length reached $2 \mathrm{~mm}$ (AOSA, 1990; Bewley and Black, 1994). Germinated seeds counted daily until complete germination and no further germination occurred.

Data were recorded daily on germination for 14 days and finally on various aspects of seed dry weight of seedling, radicle length, plumule length. Radicle, plumule and seedlings Dry weights were determined by drying the plant material at $70^{\circ} \mathrm{C}$ for $24 \mathrm{~h}$ in an oven prior to weighting. Germination percentage (GP), germination rate (GR), mean germination time (MGT) and seed stamina index (SSI) were calculated using the following formula:

$$
\begin{array}{cl}
\mathrm{GP}=(\mathrm{n} / \mathrm{N})^{*} 100 & (\text { ISTA, 2013) } \\
\mathrm{GR}=\sum(\mathrm{ni} / \mathrm{Di}) & \text { (Maguire, 1962) } \\
\mathrm{MGT}=\sum \mathrm{Dn} / \sum \mathrm{n} & \text { (Ahmad } \text { et al., 2012; Ellis and } \\
\text { Roberts, } 1981) & \\
\mathrm{SSI}=[\mathrm{GP} *(\mathrm{PL}+\mathrm{RL})] / 100 \text { (Abdul-Baki and Anderson, } \\
\text { 1970) }
\end{array}
$$

$\mathrm{n}$ : number of seeds that were germinated (on the day D), $\mathrm{N}$ : total number of seed in each petri dishes, ni: number of germinated seeds in each numeration, D: number of days counted from the beginning of germination. $\sum \mathrm{n}$ : total number of germinated seed, and PL: average of plumules length, RL: average of Radicles length.

Data obtained from experiment were subjected to analysis variance using MSTATC software and mean separation was performed by Fisher's least significant difference (LSD) test if $F$ test was significant at $\mathrm{p}<0.05$. And the Excel software was used for drawing diagrams.

\section{Results and discussion}

\section{Germination}

The ANOVA for germination percentage (GP) and Germination Rate (GR) of milk thistle (Tab. 1) show that the effect of salinity and priming on these characteristics were significant ( $\mathrm{p}<0.05$ for GP and $\mathrm{p}<0.01$ for GR). Data presented in Tab. 2 show that GP was significantly reduced by $80 \mathrm{mM} \mathrm{CaCl}_{2}$ salinity which was $16.3 \%$ less than that of 
376

control. There was no significant difference among the control, 40 and $80 \mathrm{mM} \mathrm{NaCl}$ and $40 \mathrm{mM} \mathrm{CaCl}_{2}$ in germination percentage value. The GR was the highest at control treatment (Distilled water) compared to other salinity treatments (Tab. 2). The lowest values of GR belonged to the $80 \mathrm{mM} \mathrm{CaCl}_{2}, 40 \mathrm{mM} \mathrm{CaCl}_{2}$ and $80 \mathrm{mM}$ $\mathrm{CaCl}_{2}$ by $32.5,15.6$ and $11.9 \%$ decreases compared to control, respectively.

According to results on Tab. 1, GP and GR were affected by seed priming treatments. So that, the maximum values for GP and GR belonged to $0.5 \mathrm{mM}$ SA by 11.4 and $17.3 \%$ increment compared to control, respectively. There were no significant differences between 0.5 and $1.0 \mathrm{mM} \mathrm{SA}$ treatments and hydro priming (HP) with control in this regards. Although, the $1.0 \mathrm{mM} \mathrm{SA}$ also increased GP compared to the control and HP but these increases were not significant.

\section{Mean germination time (MGT)}

Results showed that the effect of salinity on MGT was significant $(p<0.001)$. The highest $(5.71$ day $)$ and the lowest (5.02 day) MGT were recorded for $80 \mathrm{Mm} \mathrm{CaCl}_{2}$ and control, respectively. Differences between other treatments
( 40 and $80 \mathrm{NaCl}$ and $40 \mathrm{mM} \mathrm{CaCl}$ ) were not significant but GMT for them significantly increased compared to control (Tab. 2). MGT response to priming and priming $\times$ salinity were not significant (Tab. 1).

\section{Radicle and plumule length}

Analysis of variance results showed that radicle length (RL) and plumule length (PL) of seedlings were significantly affected by salinity, seed priming and interaction between these two factors (Tab. 1). The response of radicle length to salinity and seed priming was the same with plumule length. The length of radicle and plumule of milk thistle decreased significantly $(\mathrm{p}<0.001)$ with increasing in salinity concentration from $40 \mathrm{mM}$ to 80 $\mathrm{mM}$ at both $\mathrm{NaCl}$ and $\mathrm{CaCl}_{2}$ salinity solutions (Tab. 2). The highest RL and PL obtained for the control treatment that had no significant differences with $40 \mathrm{mM} \mathrm{NaCl}$ treatment. On other hand the lowest values of these parameters observed in $80 \mathrm{mM} \mathrm{CaCl} 2$ treatment with 60.2 and $59.8 \%$ decrement than those of control for RL and PL respectively.

Seed priming had a significant effect on radicle and plumule length (Tab. 3). Seed priming with SA at $0.5 \mathrm{mM}$

Tab. 1. Analysis of variance for seed priming and salinity effects on milk thistle seed germination

\begin{tabular}{|c|c|c|c|c|c|c|c|c|}
\hline $\begin{array}{l}\text { Source of } \\
\text { variation }\end{array}$ & $\mathrm{df}$ & $\begin{array}{c}\text { Germination } \\
\text { percentage }\end{array}$ & $\begin{array}{l}\text { Germination } \\
\text { rate }\end{array}$ & $\begin{array}{c}\text { Mean } \\
\text { Germination } \\
\text { Time }\end{array}$ & $\begin{array}{l}\text { Radicle } \\
\text { length }\end{array}$ & $\begin{array}{l}\text { Plumule } \\
\text { Length }\end{array}$ & $\begin{array}{l}\text { Seedling } \\
\text { dry weight }\end{array}$ & $\begin{array}{c}\text { Seed Stamina } \\
\text { Index }\end{array}$ \\
\hline Salinity & 4 & 250.62 & $2.24^{* *}$ & $0.79^{* * *}$ & $3909.5^{* * *}$ & $214.9^{\ldots * *}$ & $2.93^{*}$ & $42.3^{\ldots * *}$ \\
\hline Priming & 3 & $232.99^{\circ}$ & $0.96^{*}$ & $0.08^{\text {ns }}$ & $279^{* * *}$ & $46.7^{* * *}$ & $2.49^{*}$ & $6.3^{* * *}$ \\
\hline Salinity $\times$ Priming & 12 & $8.4^{\mathrm{ns}}$ & $0.19^{\mathrm{ns}}$ & $0.05^{\mathrm{ns}}$ & $70.3^{*}$ & 15.6 & $1.18^{\mathrm{ns}}$ & $0.5^{\mathrm{ns}}$ \\
\hline Error & 40 & 67.03 & 0.15 & 0.03 & 28 & 6.13 & 0.86 & 0.39 \\
\hline $\mathrm{CV}(\%)$ & & 13.17 & 13.6 & 3.75 & 11 & 20.64 & 8.2 & 13.38 \\
\hline
\end{tabular}

ns: Non-significant, ${ }^{*},{ }^{* *}$ and ${ }^{* * *}$ : Significant at $\alpha=0.05, \alpha=0.01$ and $\alpha=0.001$, respectively. CV: Coefficient of variation

Tab. 2. Mean comparisons of effect of salinity on milk thistle seed germination behaviors

\begin{tabular}{|c|c|c|c|c|c|c|c|}
\hline Treatment & $\begin{array}{c}\text { Germination } \\
\text { percentage }\end{array}$ & $\begin{array}{l}\text { Germination } \\
\text { rate (seed/day) }\end{array}$ & $\begin{array}{c}\text { Mean } \\
\text { Germination } \\
\text { Time (day) }\end{array}$ & $\begin{array}{l}\text { Radicle length } \\
\qquad(\mathrm{mm})\end{array}$ & $\begin{array}{l}\text { Plumule length } \\
(\mathrm{mm})\end{array}$ & $\begin{array}{l}\text { Seedling dry } \\
\text { weight (mg) }\end{array}$ & $\begin{array}{c}\text { Seed Stamina } \\
\text { Index }\end{array}$ \\
\hline Control & $66.2^{\mathrm{a}}$ & $3.26^{a}$ & $5.02^{c}$ & $63.6^{a}$ & $16.7^{\mathrm{a}}$ & $11.71^{\mathrm{a}}$ & $6.56^{a}$ \\
\hline $40 \mathrm{mM} \mathrm{NaCl}$ & $66.6^{a}$ & $3.23^{\mathrm{a}}$ & $5.19^{\mathrm{b}}$ & $60.6^{\mathrm{ab}}$ & $15.9^{\mathrm{a}}$ & $11.52^{\mathrm{a}}$ & $6.22^{\mathrm{a}}$ \\
\hline $80 \mathrm{mM} \mathrm{NaCl}$ & $61.5^{\mathrm{ab}}$ & $2.87^{\mathrm{b}}$ & $5.22^{\mathrm{b}}$ & $31.8^{c}$ & $10.6^{\mathrm{b}}$ & $11.15^{\mathrm{ab}}$ & $3.27^{\mathrm{c}}$ \\
\hline $40 \mathrm{mM} \mathrm{CaCl}_{2}$ & $61^{\mathrm{ab}}$ & $2.75^{b}$ & $5.25^{b}$ & $59.1^{b}$ & $9.9^{\mathrm{b}}$ & $11.61^{\mathrm{a}}$ & $5.23^{\mathrm{b}}$ \\
\hline $80 \mathrm{mM} \mathrm{CaCl}_{2}$ & $55.4^{\mathrm{b}}$ & $2.2^{\mathrm{c}}$ & $5.71^{a}$ & $25.3^{\mathrm{d}}$ & $6.7^{\mathrm{c}}$ & $10.5^{b}$ & $2.26^{\mathrm{d}}$ \\
\hline LSD (0.05\%) & 6.75 & 0.32 & 0.16 & 4.36 & 2.04 & 0.76 & 0.50 \\
\hline
\end{tabular}

Means followed by the same letter in each column are not significantly different according to LSD Test at $5 \%$ level

Tab. 3. Mean comparisons of effect of salicylic acid on milk thistle seed germination behaviors

\begin{tabular}{|c|c|c|c|c|c|c|}
\hline Treatment & $\begin{array}{c}\text { Germination } \\
\text { percentage }\end{array}$ & $\begin{array}{c}\text { Germination rate } \\
\text { (day) }\end{array}$ & $\begin{array}{l}\text { Radicle length } \\
(\mathrm{mm})\end{array}$ & $\begin{array}{c}\text { Plumule length } \\
(\mathrm{mm})\end{array}$ & $\begin{array}{l}\text { Seedling dry } \\
\text { weight (mg) }\end{array}$ & $\begin{array}{c}\text { Seed Stamina } \\
\text { Index }\end{array}$ \\
\hline Control & $60.2^{b}$ & $2.66^{\mathrm{b}}$ & $45.2^{b}$ & $9.6^{c}$ & $10.81^{b}$ & $4.17^{b}$ \\
\hline HP & $58.0^{\mathrm{b}}$ & $2.63^{\mathrm{b}}$ & $48^{b}$ & $11.8^{\mathrm{b}}$ & $11.29^{\mathrm{ab}}$ & $4.4^{\mathrm{b}}$ \\
\hline $\mathrm{SA}(0.5 \mathrm{mM})$ & $67.07^{\mathrm{a}}$ & $3.12^{\mathrm{a}}$ & $54.2^{\mathrm{a}}$ & $13.7^{\mathrm{a}}$ & $11.81^{\mathrm{a}}$ & $5.63^{\mathrm{a}}$ \\
\hline $\mathrm{SA}(1.0 \mathrm{mM})$ & $63.33^{\mathrm{ab}}$ & $3.03^{\mathrm{a}}$ & $45^{\mathrm{b}}$ & $12.9^{\mathrm{ab}}$ & $11.29^{\mathrm{ab}}$ & $4.62^{b}$ \\
\hline LSD (0.05\%) & 6.04 & 0.28 & 3.9 & 1.83 & 0.68 & 0.45 \\
\hline
\end{tabular}


concentration significantly increased $\mathrm{RL}$ compared to other treatments. There was no significant affect among control, hydro priming and SA $(1 \mathrm{mM})$ treatments. The difference in PL was statistically significant between control and all seed priming treatments. The concentration of $0.5 \mathrm{mM} \mathrm{SA}$ caused an increment of $29.9 \%$ in PL compared to control.

Mean comparisons showed that treatment of milk thistle seeds with SA $(0.5 \mathrm{mM})$ could prevent the decrease in radicle length caused by salinity stress at 40 and $80 \mathrm{mM}$ $\mathrm{NaCl}$. But seed priming with $0.5 \mathrm{mM} \mathrm{SA}$ at other salinity levels did not show such results (Fig. 1). Regarding to PL 0.5

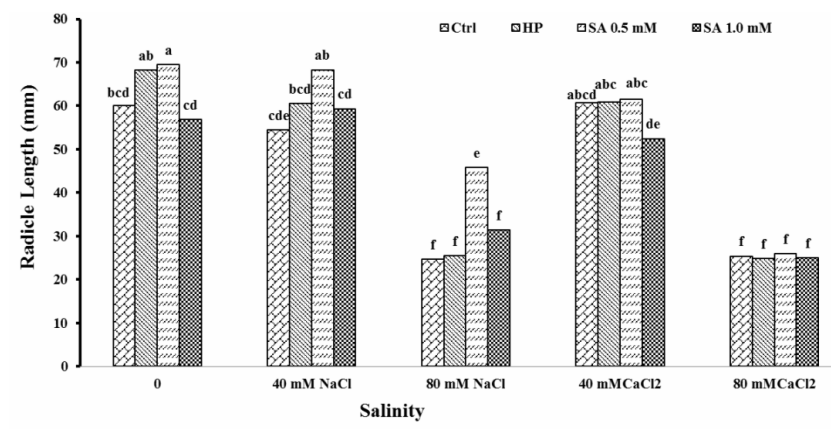

Fig. 1. Mean comparisons of the interaction of priming and salinity on radicle length of milk thistle. Ctrl: control (no priming), HP (hydro priming), SA (salicylic acid). Different letters on columns refer to significant differences between treatments at $5 \%$ level according to LSD Test

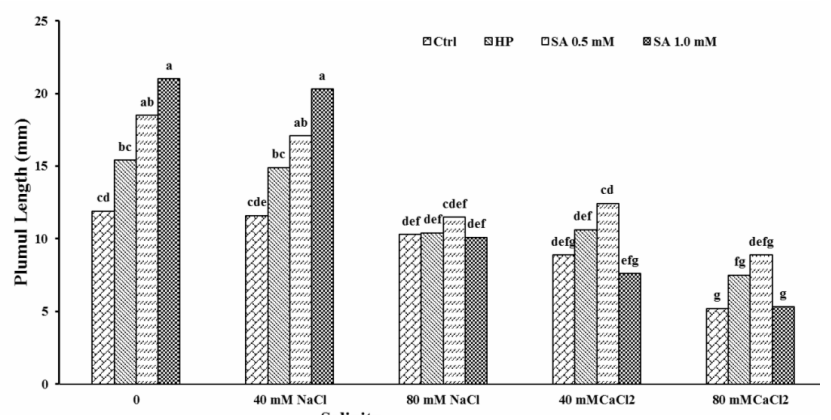

Fig. 2. Mean comparisons of the interaction of priming and salinity on plumule length). Ctrl: control (no priming), HP (hydro priming), SA (salicylic acid). Different letters on columns refer to significant differences between treatments at 5 $\%$ level according to LSD Test

and $1 \mathrm{mM}$ SA seed priming treatments only at level of 40 $\mathrm{mM} \mathrm{NaCl}$ salinity showed such behavior (Fig. 2). Moreover, seedling pretreatment with $0.5 \mathrm{mM} \mathrm{SA}$ had the highest value of these traits under normal and stress condition (Fig. 1 and 2).

Seedling dry weight

As shown in Tab. 1 the effects of salinity and seed priming on seedling dry weight were significant $(p<0.05)$. The salinity of $80 \mathrm{mM} \mathrm{CaCl} 2$ caused remarkably decreases in mentioned trait compered to control (Tab. 2). The greatest increase in seed dry weight was observed in seed priming with SA at concentration of 0.5 as $9.3 \%$ compared to non-primed seedlings ( $\mathrm{Tab}$. 3). The integration of salinity and seed priming on this trait was not significant.

\section{Seed stamina index}

According to data in Tab. 1 Seed stamina index (SSI) was significantly affected by salinity and seed priming. This trait decreased significantly under salinity of $80 \mathrm{mM} \mathrm{NaCl}$, 40 and $80 \mathrm{mM} \mathrm{CaCl}$ by $50.1,20.3$ and $65.5 \%$ when compared to the control respectively (Tab. 2). On the other hand, SSI increased with priming of seeds by $0.5 \mathrm{mM} \mathrm{SA}$ significantly compared to other treatments. Treatments of Hydro priming and $1 \mathrm{mM}$ SA did not significantly increase the SSI compared to the control (Tab. 3). The interaction of salinity and seed priming on SSI did not significant in conditions of our study.

The results of this study showed that salt stress caused significant decreases in germination and seedling growth of milk thistle. So that, the greatest decrease in the germination percentage and germination rate was observed in $80 \mathrm{mM}$ $\mathrm{CaCl}_{2}$ treatment. GP in concentrations of 40 and $80 \mathrm{mM}$ $\mathrm{NaCl}$ and $40 \mathrm{mM} \mathrm{CaCl}$ salinity and $\mathrm{GR}$ in $40 \mathrm{mM} \mathrm{NaCl}$ were not significantly reduced compared to control. From these results, it seems that those traits are partly salt-tolerant at those concentrations of salinity. A negative effect of salinity on germination of seed has been reported for many plants (Bahrani and Pourreza, 2012; Jamil et al., 2006; Sivritepe et al., 2003). Such a responses of seeds to the excess salinity might be related to the inhibitory effect of the solution low osmotic potential and/or ionic toxicity (Zhu, 2002). So, reduced water uptake by seeds under salt stress decreased metabolic and physiological processes in seeds. Results showed that seed pretreatment with SA significantly increased GP and GR compared to control. As the greatest values of them were obtained from $0.5 \mathrm{mM}$ SA. These results are in agreement with those obtained by other researchers such as Farahbakhsh (2012) on fenel, Bahrani and Pourreza, (2012) on wheat, Dallali et al. (2012) on Sulla (Hedysarum carnosum and Hedysarum coronarium). The mechanism that salicylic acid enhances seed germination is not yet clearly understood (Jamshidi-Jam et al., 2012), but according to Nun et al. (2003), salicylic acid can inhibit the activity of catalase. Reduction of catalase activity lead to increased hydrogen proxide that it can improve some seeds germination. It is possible that salicylic acid stimulates the seed germination via bio-synthesis of GA and acts as a thermogenesis inducers (Shah, 2003). Moreover increased germination rate due to seed priming may be due to increased rate of cell division in the root tips of seedlings from primed seeds (Farooq et al., 2005; Khan et al, 2009).

The different concentrations of both saline solutions led to increase the mean germination time of milk thistly seeds, as the highest average of MGT recorded for seeds under 80 $\mathrm{mM}$ calcium chloride condition. In general, salinity causes an increase in mean germination time, this may be due to effects of $\mathrm{Na}^{+}$and $\mathrm{Cl}^{-}$in the decrease of seed germination rate that was previously discussed. Increasing MGT of seed in salinity condition reported for safflower (Jamshidi-Jam et al., 2012), wheat (Afzal et al., 2006) and mustard genotypes (Sharma et al., 2013). MGT was unaffected by all priming treatments and this result is consistent with the findings of Afzal et al. (2005) on wheat.

In the present study, salt stress at $80 \mathrm{mM} \mathrm{NaCl}$ and 40 and $80 \mathrm{mM} \mathrm{CaCl}$ causes a significant decrease in radicle and plumule length and seed stamina index, but seedlings 
378

dry weight significantly decreased compared to control only at $80 \mathrm{mM} \mathrm{CaCl}_{2}$ salinity solution. Such a finding demonstrated that seedling weight of milk thistle can be partly tolerant to salinity. Decreasing of radicle and plumule length, seedling dry weight and seed stamina index as a result of salinity stress has been informed in several plants (Bahrani and Pourreza, 2012; Cicek and Cakirlar, 2002; Elouaer and Hannachi, 2012; Khan et al., 2009; Pasandipour et al., 2012). Reduced growth of these traits may be due to toxic effects of ions $\left(\mathrm{Na}^{+}\right.$and $\left.\mathrm{Cl}\right)$ that harmfully affect on plant metabolism as well as unbalanced nutrient uptake by the seedling. High salinity may inhibit radicle and plumule elongation due to slowing down the water uptake by plant (Grieve and Fujiyama, 1987; Werner and Finkelstein, 1995).

Results also showed that seed priming with $0.5 \mathrm{mM} \mathrm{SA}$ significantly increased radicle length (RL), seedling weight (SW) and seed stamina index (SSI) compared to control. But in the case of plumule length (PL) both hydro priming and salicylic acid $(0.5$ and $1 \mathrm{mM}$ ) were led to a significant increase in this trait (Tab. 3). Increase of those traits may be due to early emergence induced by priming treatment as compared to un-primed seeds (Khan et al., 2009). These results are also in confirmation with Farahbakhsh (2012) and Ghoohestani et al. (2012) showed that seeds primed with salicylic acid resulted to improve of plant growth characters. These positive effects are probably due to the stimulatory effects of priming on the early stages of germination process by mediation of cell division in germinating seeds (Sivritepe et al., 2003).

Our results also showed that interactions of salinity and priming on RL and PL were significant. So that, seed priming with $0.5 \mathrm{mM} \mathrm{SA}$ at the salinity levels of 0,40 and $80 \mathrm{mM} \mathrm{NaCl}$ led to an increase in RL compared to control. Regarding to PL, 0.5 and $1 \mathrm{mM} \mathrm{SA}$ seed priming treatments only at 0 and $40 \mathrm{mM} \mathrm{NaCl}$ salinity levels showed such a behavior (Fig. 2). According to these results treatment of milk thistle seeds with SA could prevent the decrease in plumul and radicle length under low salinity stress conditions. Khan et al. (2009) presented the same results by observing that priming of the pepper seeds with SA significantly improved radicle and plumul length under salinity and non-salinity stress conditions. These results are also in agreement with those obtained by other authors that showed saline tolerance was increased in seeds were primed with SA as indicated by shoot and root length (Afzal et al., 2005; Pasandipour et al., 2012; Tari et al., 2002). Salinity tolerance in seeds primed with 0.5 or $1 \mathrm{mM}$ salicylic acid might be due to increased activities of alpha amylase and proteinase in endosperm and the contents of soluble sugar, protein and free amino acids under stress conditions (Afzal et al., 2005; Zhang et al., 1999).

\section{Conclusions}

It is well established that seed priming is a new method for improvement of seed germination under stress and nonstress condition. Our finding also showed that seed priming especially hormonal seed priming by SA improved seed germination parameters except MGT that were investigated in this study. On other hand, saline tolerance of seeds primed with SA especially at $0.5 \mathrm{mM}$ concentration increased as indicated by radicle and plumule length. Moreover, from results of this study, we conclude that germination of seeds of milk thistly under saline stress with calcium chloride showed less resistance than sodium chloride.

\section{Acknowledgements}

We would like to thank the experts and faculty members for support and assistance. Also the authors wish to thank University of Maragheh for supporting this work.

\section{References}

Abdul-Baki AA, Anderson JD (1970). Viability and leaching of sugars from germinating barley. Crop Sci 10:31-34.

Abo-Kassem EEM (2007). Effects of salinity: Calcium interaction on growth and nucleic acid metabolism in five species of Chenopodiaceae. Turk J Bot 31:125-134.

Afzal I, Basra SMA, Farooq M, Nawaz A (2006). Alleviation of salinity stress in spring wheat by hormonal priming with ABA, salicylic acid and ascorbic acid. International J Agri Biol 8(1):23-28.

Afzal I, Basra SMA, Ahmad N, Farooq M (2005). Optimization of hormonal priming techniques for alleviation of salinity stress in wheat (Triticum aestivum L.). Caderno Pesquisa Série Biol 17(1):95-109.

Ahmad I, Khaliq T, Ahmad A, Basral SMA, Hasnain H, Ali A (2012). Effect of seed priming with ascorbic acid, salicylic acid and hydrogen peroxide on emergence, vigor and antioxidant activities of maize. African J Biotechnol 11(5):127-1132.

Allakhverdiev SI, Sakamoto A, Nishiyama Y, Inaba M, Murata $\mathrm{N}$ (2000) Ionic and osmotic effects of $\mathrm{NaCl}$-induced inactivation of Photosystems I and II in Synechococcus sp. Plant Physiol 123:1047-1056.

AOSA (1990). Association of Official Seed Analysis (AOSA). Rules for testing seeds. J Seed Technol 12:1-112.

Azooz MM (2009). Salt stress mitigation by seed priming with salicylic acid in two faba bean genotypes differing in salt tolerance. International J Agri Biol 11(4):343-350.

Bahrani A, Pourreza J (2012). Gibberlic acid and salicylic acid effects on seed germination and seedlings growth of wheat (Triticum aestivum L.) under salt stress condition. World App Sci J 18(5):633-641.

Basra SMA, Ziba MN, Afzal L, Khalig A (2002). Comparison of different invigoration techniques in wheat (Triticum aestivum L.) seeds. Pakistan J Arid Agri 5:11-16.

Bewley JD, Black M (1994). Seeds: Physiology of Development and Germination. Plenum, New York, p. 445.

Bodsworth S, Bewley JD (1981). Osmotic priming of seeds of crop species with polyethylene glycol as a means of enhancing early and synchronous germination at cool temperature. Can J Bot 59:672-676.

Carvalho RF, Piotto FA, Schmid D, Peters LP, Monteiro CC, Azevedo RA (2011). Seed priming with hormones does not alleviate induced oxidative stress in maize seedlings 
subjected to salt stress. Sci Agr 68:598-602.

Cheng Z, Bradford KJ (1999). Hydrothermal time analysis of tomato seed germination responses to priming treatments. J Experim Bot 33:89-99.

Cicek N, Cakirlar H (2002). The effect of salinity on some physiological parameters in two maize cultivars. Bulgarian J Plant Physiol 28:66-74.

Dallali H, Mallek Maalej E, Boughanmi NG, Haouala R (2012). Salicylic acid priming in Hedysarum carnosum and Hedysarum coronarium reinforces $\mathrm{NaCl}$ tolerance at germination and the seedling growth stage. Australian J Crop Sci 6(3):407-414.

Dat JF, Foyer CH, Scott IM (1998). Changes in salicylic acid and antioxidants during induced thermo tolerance in mustard seedlings. Plant Physiol 118:1455-1461.

Dell Aquila A, Tritto V (1991). Germination and biochemical activities in wheat seeds following delayed harvesting, ageing and osmotic priming. Seed Sci Technol 19:73-82.

Demir I, Mavi K (2008). Effect of salt and osmotic stresses on the germination of pepper seeds of different maturation stages. Brazilian Arch Biol Technol 51(5):897-902.

Dvorak Z, Kosina P, Walterova D, Simanek V, Bachleda P, Ulrichova J (2003). Primary cultures of human hepatocytes as a tool in cytotoxicity studies: cell protection against model toxins by flavonolignans obtained from Silybum marianum. Toxicol Lett 137(3):201-212.

Eisvand MR, Shahrosvand S, Bahman Zahedi B, Heidari S, Afrougheh S (2011). Effects of hydro-priming and hormonal priming by gibberellin and salicylic acid on seed and seedling quality of carrot (Daucus carota var. sativus). Iranian J Plant Physiol 1(4):233-239.

El-Keblawy A, Al-Rawai A (2005). Effects of salinity, temperature and light on germination of invasive Prosopis juliflora (Sw.) D C J Arid Environ 61(4):555-565.

Ellis RA, Roberts EH (1981). The quantification of aging and survival in orthodox seeds. Seed Sci Technol 9:373-409.

Elouaer MA, Hannachi C (2012). Seed priming to improve germination and seedling growth of safflower (Carthamus tinctorius) under salt stress. EurAsian J Bio Sci Eurasia J Biosci 6:76-84.

Entesari M, Sharif-Zahed F, Zare S, Farhangfar M, Dashtaki M (2012). Effects of seed priming on mung been (Vigna radiate) cultivars with salicylic acid and potassium nitrate under salinity stress. Int J Agric Res Rev 2:926-932.

Erdal S, Aydın M, Genisel M, Taspinar MS, Dumlupinar R, Kaya O, Gorcek Z (2011). Effects of salicylic acid on wheat salt sensitivity. African J Biotechnol 10(30):5713-5718.

Farahbakhsh H (2012). Germination and seedling growth in un-primed and primed seeds of fenel as affected by reduced water potential induced by $\mathrm{NaCl}$. International Research J App Basic Sci 3(4):737-744.

Farahmandfar E, Bagheri Shirvan M, Azimi Sooran S, Hoseinzadeh D (2013). Effect of seed priming on morphological and physiological parameters of fenugreek seedlings under salt stress. Intern J Agri Crop Sci 5(8):811815.

Farooq M, Basra SMA, Hafeez K, Ahmad N (2005). Thermal hardening: a new seed vigor enhancement tool in rice. J Integ Plant Biol 47:187-193.

Food Agriculture Organization. 2008. FAO land and plant nutrition management service, http://www.fao.org/ag/agl/agll/spush/.

Geneva M, Stancheva I, Sichanova M, Boychinova M, Georgiev G, Dolezal M (2008). Improvement of milk thystile (Silybum marianum L.) seed yield and quality with foliar fertilization and growth effector MD 148/II. Gen. Appl. Plant Physio Special Issue 34(3-4):309-318.

Ghoohestani A, Gheisary H, Zahedi SM, Dolatkhahi A (2012). Effect of seed priming of tomato with salicylic acid, ascorbic acid and hydrogen peroxide on germination and plantlet growth in saline conditions. Intern J Agron Plant Product 3:700-704.

Giri GS, Schillinger WF (2003). Seed priming winter wheat for germination, emergence, and yield. Crop Sci 43:21352141.

Grieve CM, Fujiyama H (1987). The response of two rice cultivars to external Na/Ca ratio. Plant Soil 103:245-250.

Horvath E, Szalai G, Janda T (2007). Induction of abiotic stress tolerance by salicylic acid signaling. J Plant Growth Regul 26:290-300.

ISTA (2013). Hand book for seedling evaluation. International Seed Testing Association, Zurich, Switzerland.

Jamil M, Lee DB, Jung KY, Ashraf M, Lee SC, Rha ES (2006). Effect of salt $(\mathrm{NaCl})$ stress on germination and early seedling growth of four vegetables species. J Cent Eur Agri 7:273-282.

Jamshidi-Jam B, Shekari F, Azimi MR, Zangani E (2012). Effect of priming by salicylic acid on germination and seedling growth of safflower seeds under $\mathrm{CaCl}_{2}$ stress. Int $\mathrm{J}$ Agric Res Rev 2:1097-1105.

Khan MA, Gulzar S (2003). Germination responses of Sporobolus ioclados, a saline desert grass. J Arid Environ 55:453-464.

Khan HA, Pervez MA, Ayub CM, Ziaf K, Balal RM, Shahid MA, Akhtar N (2009). Hormonal priming alleviates salt stress in hot Pepper (Capsicum annuum L.). Soil Environ 28(2):130-135.

Khan MA, Blackshaw RE, Marwat KB (2009). Biology of milk thistle (Sylibum marianum) and management options for growers in north-western Pakistan. Weed Biol Managem 9(2):99-105.

Korkmaz A (2005). Inclusion of acetyle salicylic acid and methyl jasmonate into the priming solution improves lowtemperature germination and emergence of sweet pepper. HortSci 40(1):197-200.

Liopa-Tsakalidi A, Zakynthinos G, Varzakas T, Xynias IN (2011). Effect of $\mathrm{NaCl}$ and $\mathrm{GA} 3$ on seed germination and seedling growth of eleven medicinal and aromatic crops. J 
380

Med Plants Res 5(17):4065-4073.

Maguire JD (1962). Speed of germination-aid in selection and evaluation for seedling emergence and vigor. Crop Sci 2:176-177.

Misra N, Misra R (2012). Salicylic acid changes plant growth parameters and proline metabolism in Rauwolfia serpentina leaves grown under salinity stress. American-Eurasian J Agric Environ Sci 12(12):601-1609.

Mohammadi GR (2009). The influence of $\mathrm{NaCl}$ priming on seed germination and seedling growth of canola (Brassica napus L.) under salinity conditions. American-Eurasian J Agric Environ Sci 5(5):696-700.

Nun NB, Plakhine D, Joel D, Mayer A (2003). Changes in the activity of the alternative oxidase in orobanche seeds during conditioning and their possible physiological function. Phytochemistry 64:235-241.

Pasandipour A, Farahbakhsh H, Saffari M, Keramat B (2012). Effects of seed priming on germination and seedling growth under salinity stress in fenugreek. International J Agri Crop Sci 4(2):779-786.

Ram GA, Bhan MK, Gupta KK, Samwal V (2005). Variability pattern and correlation studies in Silybum marianum Gareth. Fitoterapia 7:143-145.

Sayar R, Bchini H, Mosbahi M, Ezzine M (2010). Effects of salt and drought stresses on germination, emergence and seedling growth of durum wheat (Triticum durum Desf.). J Agr Res 5(15):2008-2016.

Senaratna T, Tuochell D, Bunn T, Dixon K (2000). Acetyl salicylic acid (Aspirin) and salicylic acid induce multiple stress tolerance in bean and tomato plants. Plant Growth Regul 30:157-161.

Shah J (2003). The salicylic acid loop plant defense. Curr Opin Plant Biol 6:365-371.

Shakirova FM, Sakhabutdinova AR, Bezrukova MV, Fatkhutdinova RA, Fatkhutdinova DR (2003). Changes in the hormonal status of wheat seedlings induced by salicylic acid and salinity. Plant Sci 164:317-22.

Sharma P, Sardana V, and Banga SS (2013). Salt tolerance of Indian mustard (Brassica juncea) at germination and early seedling growth. Environ Experimen Biol 11:39-46.

Shokrpour M, Moghaddam M, Mohammadi SA, Javanshir A (2007). Genetic properties of milk thistle ecotype from Iran for morphological and flavonilignans characters. Pak J Biol Sci 10(19):3266-3271.

Sivritepe N, Sivritepe HO, Eris A (2003). The effects of $\mathrm{NaCl}$ priming on salt tolerance in melon seedling grown under saline condition. Sci Hort 97:229-237.
Tanji KK (1995). Agricultural salinity assessment and management. Scientific Publisher, Jodhpur, India, p. 619.

Tari I, Csiszar J, Szalai G, Horvath F, Pecsvaradi A, Kiss G, Szepesi A, Szabo M, Erdei L (2002). Acclimation of tomato plants to salinity stress after a salicylic acid pretreatmemt. Acta Biol Szegediensis 46:55-56.

Taylor AG, Harman GE (1990). Concepts and technologies of selected seed treatments. Ann Rev Phytopathol 28:321339.

Thiam M, Champion A, Diouf D, Oureye M (2013). NaCl effects on in vitro germination and growth of some senegalese cowpea (Vigna unguiculata (L.) Walp.) cultivars. Hindawi Publishing Corporation ISRN Biotechnology 111.

Veres T, Tyr S (2012). Milk thistle (Silybum marianum L. Gaertn) as a weed in sustainable crop rotation. Rese J Agri Sci 44(2):118-122.

Werner JE, Finkelstein RR (1995). Arabidopsis mutants with reduced response to $\mathrm{NaCl}$ and osmotic mutants with reduced response to $\mathrm{NaCl}$ and osmotic stress. Physiol Plant 93:659-666.

Yalpani N, Enyedi AJ, Leon J, Raskin I (1994). Ultraviolet light and ozone stimulate accumulation of salicylic acid and pathogenesis related proteins and virus resistance in tobacco. Planta 193:373-376.

Yamaguchi T, Blumwald E (2005). Developing salt-tolerant crop plants: challenges and opportunities. Trends Plant Sci 10 (12):615-620.

Zahedi SM, Nabipour M, Azizi M, Gheisary H, Jalali M, Amini Z (2011). Effect of kinds of salt and its different levels on seed germination and growth of basil plant. World App Sci J 15(7):1039-1045.

Zehtab-Salmasi S, Moghbeli S 2008. Effects of temperature and salinity on germination of milk thistle (Sulibum marianum). Res J Agron 2(2):31-35.

Zhang S, Gao J, Song J, Zhang SG, Gao J Y, Song J Z. (1999). Effects of salicylic acid and aspirin on wheat seed germination under salt stress. Plant physiology communications 35:29-32.

Zhu JK (2002). Salt and drought stress signal transduction in plants. Annu Rev Plant Biol 53:247-273. 